ARTigo Original

Original Article

\title{
Lifestyle Changes after Osteoporotic Fractures in Elderly Women ${ }^{*}$
}

\section{Mudanças dos Hábitos de Vida após Fratura por Osteoporose em Mulheres Idosas}

\author{
Marcelo Medeiros Pinheiro ${ }^{(1)}$, Charles Heldan de Moura Castro ${ }^{(2)}$, \\ Alberto Frisoli Júnior( ${ }^{(3)}$ e Vera Lúcia Szejnfeld ${ }^{(4)}$
}

\begin{abstract}
Objective: health promotion and disease prevention activities directed to osteoporosis might help to reduce the rate of osteoporotic fractures among elderly people. Methods: in order to check whether osteoporotic women modify their habits after the fracture, 518 postmenopausal white Brazilian elderly women were recruited from the outpatient clinic of the Rheumatology Division (122 of them with fracture) and were followed for one year. Questionnaire of evaluation was based on the European Vertebral Osteoporosis Study (EVOS) and inquiries about topics related to falls, bone mass and fracture. Lateral thoracic and lumbar radiographs were taken according to a standard protocol in order to verify vertebral fracture. Bone mineral density was measured using a bone densitometer (Lunar DPX, Madison, WI). Women's behavior was analyzed before and after the fracture. Results: before the fracture, $34 \%$ of them had poor health perception, $40.2 \%$ walked at least half an hour per day, $14.7 \%$ used canes, $56.6 \%$ complained of dizziness, $59.6 \%$ scattered rugs, $78.9 \%$ used public transportation, $21.1 \%$ used car, and $36.8 \%$ wore leather instead of rubber sole. After the fracture, $66.4 \%$ of those women had worse health perception; $69.7 \%$ became more sedentary, $27.9 \%$ used more canes, $63.4 \%$ complained of more dizziness, $38.3 \%$ removed rugs, $68.1 \%$ changed from public to private car transportation, and $55.7 \%$ modified their shoes from leather to rubber sole. Risk factors related to bone mass did not change before and after the fractures. Conclusions: these
\end{abstract}

\section{RESUMO}

Objetivo: atividades de promoção de saúde e prevenção direcionadas para osteoporose podem ajudar a reduzir a taxa de fraturas osteoporóticas na população idosa. Métodos: para avaliar se mulheres com osteoporose modificam seus hábitos de vida após a fratura, selecionamos 518 mulheres idosas caucasianas de nosso Serviço Ambulatorial de Reumatologia (122 com fratura), que foram seguidas por um ano. O questionário de avaliação foi baseado no European Vertebral Osteoporosis Study (EVOS) e contém tópicos relacionados com queda, massa óssea e fratura. Radiografias lateral da coluna torácica e lombar foram realizadas de acordo com protocolo padrão para verificar fratura vertebral. Densidade mineral óssea foi medida por meio de densitômetro Lunar DPX, Madison, WI. O comportamento das mulheres foi analisado antes e após a fratura. Resultados: antes da fratura, 34\% das mulheres tinham pior percepção da saúde, 40,2\% caminhavam pelo menos meia hora por dia, 14,7\% usavam bengalas, 56,6\% queixavam-se de tonturas, 59,6\% possuíam tapetes espalhados pela casa, 78,9\% usavam transporte público, $21,1 \%$ utilizavam transporte privado (carro) e 36,8\% usavam solado de couro e não de borracha. Após a fratura, 66,4\% das mulheres tinham pior percepção da saúde; $69,7 \%$ ficaram mais sedentárias, 27,9\% usavam mais bengalas, 63,4\% queixavam-se de mais tonturas, 38,3\% tinham retirado os tapetes de casa, $68,1 \%$ trocaram o transporte público por privado e 55,7\% modificaram o solado dos sapatos de couro para borracha. Fatores de risco relacionados com a massa óssea não foram modificados após a fratura. Conclusões: estes achados sugerem que mulheres

\footnotetext{
* Setor de Doenças Osteometabólicas, Disciplina de Reumatologia, Departamento de Medicina, Universidade Federal de São Paulo/Escola Paulista de Medicina, São Paulo, Brazil. This paper was approved to be presented in a poster session at the American College Rheumatology (Philadelphia, November 2000) and was financially supported by Capes. Recebido em 18/06/02. Aprovado, após revisão, em 23/03/03.

1. Pós-graduando em doutorado na disciplina de Reumatologia pela UNIFESP/EPM.

2. Pós-graduando em doutorado na disciplina de Reumatologia pela UNIFESP/EPM.

3. Médico assistente doutor da disciplina de Geriatria na UNIFESP/EPM.

4. Professora adjunta da disciplina de Reumatologia na UNIFESP/EPM.

Endereço para correspondência: Marcelo M. Pinheiro. Disciplina de Reumatologia, UNIFESP, Rua Botucatu, 740, terceiro andar, Vila Clementino, CEP 04023-900, São Paulo-SP. Fone: 55 (11) 5576-4239; fax: 55 (11) 5570 6665; e-mail: mpinheiro@uol.com.br
} 
findings suggested that women modify only lifestyle habits related to falls but not those related to bone mass after osteoporotic fracture. Further research is needed in order to check which intervention strategies may lead to better results in preventing osteoporotic fractures.

Keywords: fracture, lifestyle changes, osteoporosis, elderly women.

\section{INTRODUCTION}

Reducing mortality from osteoporotic fractures remains a priority. As an approach to reach it, general practitioners have been encouraged to target patients with established osteoporosis for secondary prevention.

Secondary prevention of several diseases such as heart disease, hypertension and diabetes mellitus is widely viewed as likely to be more successful and cost effective than primary prevention. Significant reductions in fracture rate among osteoporotic patients have been reached with hormone replacement therapy (HRT), alendronate treatment, increase of calcium intake, regular exercises and sunlight exposure ${ }^{(1)}$. Therefore there is convincing evidence confirming that secondary prevention is effective. However, research on primary care intensive interventions encouraging lifestyle changes among osteoporotic patients needs to be evaluated in order to verify possible measurable benefit and effectiveness.

Fall-related injuries are the main cause of mortality due to unintentional trauma among American elderly. In 1989, 9,187 deaths among elderly were attributed to falls. About one third of all deaths from falls occurred among people aged 85 years or older. Prevention of falls is a critical issue that requires extensive intervention to be successful ${ }^{(2,3)}$. Padded protectors recommended to be worn by the fallprone elderly in order to minimize impact have been adopted only by a few. Routine physical activity may prove to be one of the best protective mechanisms for preventing falls ${ }^{(4)}$.

Distal forearm and hip fractures are closely related to falls ${ }^{(5,6)}$. Many risk factors for falls and hip fracture have been described. Long-acting antidepressants, low sunlight exposure, institutionalization, low physical activity ${ }^{(7-10)}$, nutritional factors (low levels of ascorbic acid, vitamin $\mathrm{K}$, fructosamine, animal protein and calcium intake, as well as excessive intake of vitamin $\mathrm{A})^{(11-16)}$ and smoking ${ }^{(17,18)}$ are the most relevant of them. Even though so many evidences confirm that primary prevention interventions could idosas modificam somente os hábitos de vida relacionados com quedas, mas não aqueles relacionados com a massa óssea após a fratura por osteoporose. Pesquisas são necessárias a fim de avaliar quais estratégias de intervenção podem ocasionar melhores resultados na prevenção de fraturas por osteoporose.

Palavras-chave: fratura, mudanças de hábitos de vida, osteoporose, mulheres idosas

be effective to reduce fractures, it seems that none of these data is powerful enough to trigger changes in lifestyle before the event. Lifetime compliance with any therapy is likely to be modest. For example, one third or more of American white women begin HRT at the menopause but less than $10 \%$ continue it for more than 5 years ${ }^{(19-21)}$.

While there is intensive research on risk factors for falls and hip fracture much less attention has been paid to the real impact of current primary and secondary preventive practices in primary care. In order to check whether osteoporotic women modify their habits after a fracture at any site, we studied lifestyle changes among these women using a case-control study design.

\section{MATERIAL AND METHODS}

A total of 518 postmenopausal Brazilian white women have been followed for more than one year. They were recruited between January 1997 and July 1999 from the outpatient clinic at Hospital São Paulo. Women with history of endocrinopathy, nephropathy, gastroenteropathy, rheumatic diseases, asthma, malnutrition and prolonged immobility period (more than two months) were excluded, as well as patients with any kind of cognitive impairment. Asian and no Caucasian women were not included. One hundred twenty two women of the total sample $(38.4 \%)$ had osteoporotic fracture.

All women answered a questionnaire particularly developed for this research and based on literature data. The inquiries applied were from the European Vertebral Osteoporosis Study (EVOS) ${ }^{(22)}$ and also included another questionnaire according to aspects directly related to falls, bone mass and fracture (Appendix 1). EVOS is a multinational multicentre population-based cross-sectional survey ascertaining prevalent cases of radiographically determined vertebral deformity together with an interviewer-administered questionnaire aimed at identifying current and previous aspects of lifestyle and other factors relevant to the development of vertebral osteoporosis. 
The structured questionnaire included details on personal and medical history, drug use (diuretics, corticosteroids, bisphosphonates, sodium fluoride, calcitonin and anabolic steroids), diet habits (amount of dietary calcium was assessed by a food-frequency questionnaire in which current and past exposure in periods of all life were evaluated), smoking, alcohol intake, exercise (walking, and number of hours spent sitting and lying down per day nowadays and in the past), falls during the last year, reproductive hormonal factors including age at menarche, age at menopause, hysterectomy, oophorectomy, pregnancy history, breast-feeding and use of exogenous hormones, both for oral contraceptive purposes and taken as replacement therapy at or around the menopause as well as date of starting and stopping hormone replacement therapy. Age, weight, height, body mass index (BMI) and familial history of hip fracture (FHHF) were also recorded. The questionnaire was phrased to ascertain the most strenuous level of activity carried out daily during each of the three age periods, according to EVOS. The definition of grade of physical activity was the same used in $\operatorname{EVOS}^{(22,23)}$.

In order to verify lifestyle changes related to risk factors associated to falls and bone mass, we investigated the following topics: 1- Environmental adaptations and home modifications such as kind of shoes, transports, adequate lighting, placement of bright colored tape or nonskid mats on steps, removal of scattered rugs, objects in the pathway, installation of night-lights, installation of bathtub nonskid mats or strips and use of canes; 2- Risk factors related to bone mass such as milk intake and physical activity; 3- Age-related physiological changes such as dizziness (confirmed by Romberg test), health perception, fear of falling, number of falls during last year, visual acuity and hearing loss.

In order to check whether patients had changed their habits, women's behaviour was analysed before and after the fracture.

Peripheral fractures were identified only by self-report. Lateral thoracic and lumbar radiographs were taken according to a standard protocol. Thoracic films were centered at T7 and lumbar films at L2. Six points were marked on each vertebral body from T4 to L4 in order to describe vertebral shape, and measurements of anterior, middle and posterior height were recorded. Vertebral height ratios were calculated from these measurements and the presence of vertebral deformity was defined according to Riggs's method.
All participants had at least one bone mass measurement showing osteoporosis at the spine or femoral neck, according to the WHO criteria. Bone mineral density was measured using a bone densitometer (Lunar DPX, Madison, WI).

All women gave written informed consent and the protocol was approved by the UNIFESP/EPM Ethical Committee.

\section{STATISTICAL ANALYSES}

Mean and standard deviation (SD) results were reported for demographic and clinical parameters. Percentile comparison between before and after the fracture was performed to all aspects related to bone mass and falls. Values of $p$ less than 0.05 were considered significant.

\section{RESULTS}

Demographic characteristics of all women are shown in Table 1, and lifestyle habits that influence mainly bone mass before and after the fracture are listed on Table 2 .

TABLE 1

Demographic CHARACTERISTICS OF 122 WOMEN WITH OSTEOPOROTIC FRACTURE

\begin{tabular}{lc}
\hline & (mean \pm SD) \\
\hline Age (years) & $75 \pm 8$ \\
Weight $(\mathrm{kg})$ & $56.2 \pm 10.5$ \\
Height $(\mathrm{m})$ & $1.48 \pm 0.07$ \\
BMI $\left(\mathrm{kg} / \mathrm{m}^{2}\right)$ & $25.5 \pm 4.3$ \\
Years since menopause & $27.1 \pm 9.5$ \\
\hline
\end{tabular}

TABLE 2

LIFESTYLE HABITS RELATED TO BONE MASS BEFORE AND AFTER FRACTURE

\begin{tabular}{cccr}
\hline & Before (\%) & After (\%) & $p$ Value \\
\hline Milk intake: < 1glass & 12.1 & 10.8 & 0.813 \\
1-2 glasses & 55.6 & 57.1 & 0.852 \\
> 2 glasses & 32.3 & 32.1 & 0.964 \\
Physical activity: none & 51.6 & 69.7 & $<0.001$ \\
1/2 to 1 h/day & 40.2 & 27.9 & $<0.001$ \\
More than 1 h/day & 8.2 & 2.4 & $<0.001$ \\
\hline
\end{tabular}

The majority of participants did not practice any physical activity before fracture (51.6\%) and this trend became more evident after the event (69.7\%). Milk intake has not 
changed after the fracture. Smoking, alcohol intake and prolonged immobility were not statistically different before and after fracture (data not shown).

Before fracture, two thirds of the patients had good health perception. After the event the same proportion answered that they had poor health perception. Fear of falling was not different before and after fracture (Table 3).

TABLE 3

FeAr of FALLing AND HeALTH PERCEPTION BEFORE AND AFTER FRACTURE

\begin{tabular}{|c|c|c|c|}
\hline & Before (\%) & After $(\%)$ & $p$ Value \\
\hline Fear of falling & 79.5 & 81.2 & 0.879 \\
\hline Health perception: good & 66 & 33.6 & $<0.001$ \\
\hline poor & 34 & 66.4 & $<0.001$ \\
\hline
\end{tabular}

Table 4 shows that after presenting a fracture, women changed their shoes from leather to rubber sole $(36.8 \%$ vs. $55.7 \%)$, began to use more canes $(14.7 \%$ vs. $27.9 \%)$, stopped using public transportation and started using private car $(21.1 \%$ vs. $70.1 \%)$, removed rugs at home (59.6\% vs. $38.3 \%)$, complained more of dizziness (46.6\% vs. $63.4 \%)$ and increased the number of falls during last year $(36.1 \%$ vs. $52.6 \%$ ). Romberg's test was positive in $78.7 \%$ of them. Visual and hearing impairment were referred by $41.9 \%$ of the patients. They have not changed home illumination , installed handrail or asked for an anti-slipper floor at the steps after the fracture.

TABLE 4

LIFESTYLE HABITS RELATED TO FALLS BEFORE AND AFTER FR ACTURE

\begin{tabular}{|c|c|c|c|}
\hline & Before (\%) & After $(\%)$ & $p$ Value \\
\hline More than one fall during last year & 36.1 & 52.6 & $<0.001$ \\
\hline Use of rugs at home & 59.6 & 38.3 & $<0.001$ \\
\hline Use of cane & 14.7 & 27.9 & $<0.001$ \\
\hline Kind of shoes: leather & 63.2 & 36.8 & $<0.001$ \\
\hline rubber & 44.3 & 55.7 & $<0.001$ \\
\hline \multirow{2}{*}{ Means of transportation: public } & 78.9 & 21.1 & $<0.001$ \\
\hline & 29.9 & 70.1 & $<0.001$ \\
\hline Home lighting & 93.4 & 94.7 & 0.845 \\
\hline Dizziness & 46.6 & 63.4 & 0.367 \\
\hline
\end{tabular}

\section{DISCUSSION}

Most of the falls in the elderly are probably due to intrinsic (host) and extrinsic (environmental) factors. Although there has been a great deal of progress in the identification of intrinsic risk factors, investigation of extrinsic factors remains more limited. Environmental factors are thought to be particularly important in falls among the more active elderly while intrinsic factors may be more representative this role among the frail ${ }^{(24)}$.

Fears and apprehensions are often cited as contributing factors to decreased quality of life, however questions related to worry about the future are rarely included in generic quality of life questionnaires. Our results agree with Lydick who concluded that osteoporosis-related fears appear to explain a small but significant percentage of the variation in quality of life of middle-aged women ${ }^{(25)}$. Hip fracture, spinal deformity, decreased mobility, pain from fractures and stature loss are common physical consequences of osteoporosis that often lead to difficulty in performing daily activities, feelings of insecurity and unattractiveness, depression and social isolation. We observed that health perception was compromised among women with vertebral and hip fracture.

Patients have not changed their habits in relation to smoking, immobility and alcohol intake after a fracture. Only a minority of our patients had these habits and it could explain the poor correlation observed. Although the impact of these risk factors on fracture's pathophysiology is not well established, their detection and modification whenever possible during any period of the life is surely an important and potential preventive strategy against osteoporosis.

Regular physical activity has been a priority for bone loss prevention and has been emphasized in many researches ${ }^{(26-30)}$. Nevertheless, most of our patients had become more sedentary after fracture. Fear of falling could be an explanation for the sedentary behavior, however this feeling was not different before and after fracture. Impaired physical conditions could be another hypothesis that was not investigated in this study ${ }^{(31)}$.

Home hazards usually seen among elderly people living environments include inappropriately placed furniture or objects, scattered rugs and slippery surfaces ${ }^{(32,33)}$. The relationship between home hazards and falls is most frequently ascertained by self-report ${ }^{(34-36)}$. Old people implicate environmental factors in one third to half of 
their falls ${ }^{(37,38)}$. The majority of studies is conducted retrospectively and is therefore limited by the subject's ability to remember falls and the circumstances precipitating them ${ }^{(39)}$. Prospective studies of falls in community-residing older adults have also found an association between falls and the home environment. In a prospective cohort study of 325 community-residing elderly, nonfrail individuals, the risk of falling increased as the number of hazards in home was greater ${ }^{(40)}$.

Our results suggest that women have modified lifestyle habits, mainly those related to falls. They have not cared about milk intake and physical activity, well known factors associated to bone loss. Even after being told by doctors that milk and physical exercises are good to bone health, women have not changed their previous habits. Furthermore, they have changed lifestyle habits only after the event and not before it, even knowing the importance those habits have on risk of fractures.

Our study had some limitations. Despite the fact we have included questions about drugs related to bone metabolism, we have not searched use of medications associated to falls such as psychotropic, antiparkinson, antidepressants drugs, sedatives and hypnotics. Notwithstanding all women have been followed during the last year by the same physician, receiving the same oral information, we have not given them any special classes or a written manual describing measures to improve bone mass or how to avoid falls. In addition, due to the cross-sectional nature of this study, we have not seen the patients before, during and/or after the fracture. We have just inquired them about the fracture they have suffered and its circumstances. Memory limitations common to this population may have led to some biases.

The real impact of habits and home modifications on falls and fracture rates in elderly women is controversial. Hornbrook et al. conducted a fall prevention program randomized trial and documented only a modest reduction in the number of falls $(7 \%)^{(41)}$. On the other hand, Schwarz et al. reported statistically significant reduction of falls after home hazards modification ${ }^{(42)}$.

Lifestyle changes can modify coronary heart disease and reduce mortality from $\mathrm{it}^{(43)}$. Exercise programs have reduced mortality rates after myocardial infarction by $20 \%{ }^{(44)}$, and stopping smoking is associated with halving of mortality ${ }^{(45)}$. Reductions in mortality from dietary changes have been attributed to a protective effect from certain foods, particularly fruit and vegetables, in addition to cholesterol lowering ${ }^{(46,47)}$. As heart attack is clearly a very traumatic health event with imminent death risk, it might be more persuasive and easier to convince people at risk to adopt lifestyle changes than it is to reach the same objective with osteoporotic patients.

There is no convincing evidence that the disease itself is sufficient to motivate people to adopt lifestyle changes. People's willingness and ability to adopt lifestyle change is a complex issue in which lay understandings of disease causation and risk, and a range of socioeconomic factors is important. Research on lifestyle and health behavior has largely focused on general population where there is considerable evidence that people are generally aware of health risks associated with particular behaviors. However, knowledge alone is not enough to bring about changed behavior ${ }^{(48)}$. In addition, social factors such as people's environment, social and material resources and appropriateness of lifestyle behavior to people's stage in life cycle affect the lifestyle choices people may adopt ${ }^{(49)}$.

Research on patients with established disease is limited. However, research on patients with non-insulin dependent diabetes and alcoholic liver disease has indicated that, as demonstrated in general population, beliefs about the condition, interpretations of lifestyle advice and a range of social factors similarly influence "at risk" patient's ability and willingness to adopt and maintain lifestyle changes ${ }^{(50-51)}$. Scientific evidence supports that environmental factors, especially dietary calcium intake and physical activity, can favorably modulate bone mass of adolescent girls and young women ${ }^{(52)}$. A number of potentially modifiable factors affecting risk of falling has been consistently identified and this risk increases with the number of risk factors present. There seems to be considerable potential to increase secondary prevention of osteoporotic fractures in general practice. Thus, given the number of factors involved, multifactorial risk interventions may be the most promising strategy.

It seems that the majority of osteoporotic patients know what to do, but they are not convinced that lifestyle changes will play an important role in reduction of osteoporotic fracture risk. Our results suggest that in spite of the great deal of evidence showing the importance of skeletal risk factors related to fractures, women at risk are not aware of and do not adopt healthy habits in order to avoid or minimize bone loss. Further research is needed in order to check which intervention strategies may lead to better results in preventing osteoporotic fractures. 
APPENDiX 1

Questionnaire about Bone Mass and Fracture

- After the fracture, have you changed your physical activity? yes $\square \quad$ no $\square \quad$ don't know $\square$

- After the fracture, have you changed your milk intake? yes $\square \quad$ no $\square \quad$ don't know $\square$

- After the fracture, have you changed alcohol intake? yes $\square$ no $\square$ don't know $\square$

- After the fracture, have you changed smoking habits? yes $\square$ no $\square \quad$ don't know $\square$

- After the fracture, have you been immobilized? yes $\square$ no $\square \quad$ don't know

APPENDIX 2 Questionnaire about Falls and Fracture

- After the fracture, how do you describe your health perception? $\operatorname{good} \square \quad$ bad $\square$

- After the fracture, have your fear of falling changed? yes $\square$ no $\square \quad$ don't know $\square$

- After the fracture, has the frequency of falls increased? yes $\square \quad$ no $\square \quad$ don't know $\square$

- Do you have rugs at home? yes $\square \quad$ no $\square \quad$ don't know $\square$

- Have you changed the rugs of your house after the fracture? yes $\square \quad$ no $\square \quad$ don't know $\square$

- Is there adequate lighting into the rooms at night? yes $\square \quad$ no $\square \quad$ don't know $\square$
- Have your worry about lighting rooms improved at night after fracture?

yes $\square$ no $\square \quad$ don't know $\square$

- Do you use cane?

yes $\square \quad$ no $\square \quad$ don't know $\square$

- After the fracture, do you need more the cane?

yes $\square \quad$ no $\square \quad$ don't know $\square$

- Is there staircases at your house?

yes $\square \quad$ no $\square \quad$ don't know $\square$

- Is there handrail at your house?

yes $\square$ no $\square \quad$ don't know $\square$

- Is there anti-slipper floor at your house?

yes $\square$ no $\square \quad$ don't know $\square$

- Have you changed any of these articles after the fracture? staircases $\square \quad$ handrail $\square \quad$ anti-slipper floor $\square$

- Do you feel dizzy?

yes $\square \quad$ no $\square \quad$ don't know $\square$

- Have your dizziness perception changed after the fracture? yes $\square$ no $\square \quad$ don't know $\square$

- Which mean of transportation did you use to use before the fracture?

public $\square \quad$ private $\square$

- Have you changed your mean of transportation after the fracture? yes $\square \quad$ no $\square \quad$ don't know $\square$

- What kind of shoes did you use to use before the fracture? rubber sole $\square \quad$ leather sole $\square$

- Have you changed your kind of shoes after the fracture? yes $\square \quad$ no $\square \quad$ don't know $\square$ 


\section{REFERENCES}

1. Wilkinson TJ, Elliot JR, Gilchrist NL: Asymptomatic low bone mineral density in otherwise healthy people: four year follow-up. N Zeal Med J 1993;106(963):377-8.

2. Kannus P: Preventing osteoporosis, falls, and fractures among elderly people. Br Med J 1999;318:205-6.

3. Close J, Ellis M, Hooper R: Prevention of falls in the elderly trial (PROFET): a randomized controlled trial. Lancet 1999;353: 93-7.

4. Barrett JA, Baron JA, Karagas MR, Beach ML: Fracture risk in the US Medicare population. J Clin Epidemiol 1999;52:243-9.

5. Jacobsen SJ, Sargent DJ, Atkinson EJ: Contribution of weather to the seasonally of distal forearm fractures: a population-based study in Rochester, Minnesota. Osteoporos Int 1999;9:254-9.

6. Jonsson B, Bengner U, Redlund-Johnell I, Johnell O: Forearm fractures in Malmo, Sweden. Changes in the incidence occurring during the 1950s, 1980s, and 1990s. Acta Orthop Scand 1999;70: 129-32.

7. Norton R, Campbell AJ, Reid IR: Residential status and risk of hip fracture. Age Ageing 1999;28:135-9.

8. Kanis JA, Johnell O, Gulberg B: Risk factors for hip fracture in men from southern Europe: the MEDOS study. Osteoporos Int 1999;9: 45-54.

9. Guo Z, Wills P, Wiitanen M: Cognitive impairment, drug use, and the risk of hip fracture in persons over 75 years old: a communitybased prospective study. Am J Epidemiol 1998;148:887-92.

10. LeBoff MS, Kohlmeier L, Hurwitz S: Occult vitamin D deficiency in post-menopausal US women with acute hip fracture. JAMA 1999;281:1505-11.

11. Falch JA, Mowe M, Bohmer T: Low levels of serum ascorbic acid in elderly patients with hip fracture. Scand J Clin Lab Invest 1998;58: 225-8.

12. Munger RG, Cerhan JR, Chiu B C-H: Prospective study of dietary protein intake and risk of hip fracture in postmenopausal women. Am J Clin Nutrition 1999;69:147-52.

13. Feskanich D, Weber P, Willet WC: Vitamin K intake and hip fractures in women: a prospective study. Am J Clin Nutr 1999;69: 74-9.

14. Feskanich D, Willet WC, Stampfer MJ, Colditz GA: Milk, dietary calcium, and bone fractures in women: a 12-year prospective study. Am J Public Health 1997;87:992-7.

15. Jamal SA, Stone K, Browner SW: Serum fructosamine level and the risk of hip fracture in elderly women: a case-cohort study within the Study of Osteoporotic Fractures. Am J Med 1998;105: 488-93.

16. Melhus H, Michaelsson K, Kindmark A: Excessive dietary intake of vitamin $\mathrm{A}$ is associated with reduced bone mineral density and increased risk for hip fracture. Ann Int Med 1998;129:770-8.

17. Melhus H, Michaelsson K \& Holmberg L: Smoking, antioxidant vitamins, and the risk of hip fracture. J Bone Miner Res 1999;14: 129-35.

18. Cornuz J, Feskanich D, Willet WC, Colditz GA: Smoking, smoking cessation, and risk of hip fracture in women. Am J Med 1999;106: 311-14.

19. Melton LJIII: How many women have osteoporosis now? J Bone Miner Res 1985;10:175-7.
20. Melton LJIII, Kan SH, Frye MA: Epidemiology of vertebral fractures in women. Am J Epidemiol 1989;129:1000-11.

21. Orwoll ES, Bauer DC and Study of Osteoporotic Fractures Research Group: Axial bone mass in older women. Ann Int Med 1996;124(2): 187-96.

22. O'Neill TW, Cooper C, Algra D: Design and development of a questionnaire for use in a multicentre study of vertebral osteoporosis in Europe: the European Vertebral Osteoporosis Study (EVOS). Rheumatology European 1985;24:75-81.

23. O'Neill TW, Cooper C, Cannata JB: Reproducibility of a questionnaire on risk factors for osteoporosis in a multicentre prevalence survey: The European Vertebral Osteoporosis Study. Int J Epidemiol 1994;23(3):559-65.

24. Nevitt M: Falls in older persons: risk factors and prevention, in The Second Fifty Years: Promoting Health and Preventing Disability (Berg RL \& Cassells JS, eds.). National Academy Press, Washington, DC, 1990.

25. Lydick E, Martin A, Yawn B: Impact of fears on quality of life in patients with silent disease: osteoporosis. Clin Therapeutics 1996;18(6):1307-15.

26. Silman AJ, O'Neill TW, Cooper $\mathrm{C}$ and The EVOS Group: Influence of physical activity on vertebral deformity in men and women: results from the European Vertebral Osteoporosis Study. J Bone Min Res 1997;12(5):813-9.

27. Gregg EW, Cauley JA, Seeley DG: Physical activity and osteoporotic fracture risk in older women. The Study of Osteoporotic Fractures Research Group. Ann Int Med 1998;129:81-8.

28. Stillman RJ, Lohman TG, Slaughter MH, Massey BH: Physical activity and bone mineral content in women aged 30 to 85 years. Med Sci Sports Exercise 1986;18:576-80.

29. Lord SR, Ward JA, Williams P, Zivanovic E: The effects of a community exercise program on fracture risk factors in older women. Osteoporos Int 1996;6:361-7.

30. Alloio B: Risk factors for hip fracture not related to bone mass and their therapeutic implications. Osteoporos Int 1999; Suppl 2:9-16.

31. Greendale GA, Barrett-Connor E, Ingles S, Haile R: Late physical and functional effects of osteoporotic fracture in women: The Rancho Bernardo Study. JAGS 1995;43:955-61.

32. Hornbrook MC, Stevens VJ, Wingfoeld DJ: Preventing falls among community-dwelling older persons: Results from a randomized trials. Gerontologist 1994;34:16-23.

33. Rubenstein LZ, Robbins AS, Schulman BL: Falls and instability in the elderly. JAGS 1988;36:266-78.

34. Nevitt MC, Cummings ST, Kidd S, Black D: Risk factors for recurrent nonsyncopal falls: a prospective study. JAMA 1989;261: 2663-8.

35. Lau EM, Donnan SP: Falls and hip fractures in Hong Kong Chinese. Public Health 1990;104:117-21.

36. Tideiksaar R: Geriatric falls in the home. Home Healthcare Nurse 1986;4:14-23.

37. Rubenstein LZ, Robbins AS, Schulman BL: Falls and instability in the elderly. JAGS 1988;36:266-78.

38. Maki BE, Holliday PJ, Topper AK: Fear of falling and postural performance in the elderly. Journal of Gerontology 1991;46:M123M131.

39. Cummings SR, Nevitt MC, Kidd S: The limited accuracy of recall of falls in the elderly. JAGS 1988;36:613-6. 
40. Speechley ME, Tinetti M: Falls and injuries in frail and visorous community elderly persons. JAGS 1991;39:46-52.

41. Hornbrook MC, Stevens VJ \& Wingfoeld JF: Preventing falls among community-dwelling older persons: Results from randomized trials. Gerontologist 1994;34:16-23.

42. Schwarz DF, Grisso JA, Miles CG: A longitudinal study of injury morbidity in an African-American population. JAMA 1994; 271:755-60.

43. Ornish D, Brown SE, Scherwit LW: Can lifestyle changes reverse coronary heart disease? The lifestyle heart trial. Lancet 1990;336: 129-33.

44. O'Connor GT, Buring JE, Yusuf S: An overview of randomized trials of rehabilitation with exercise after myocardial infarction. Circulation 1989;80:234-44.

45. Daly LE: Long term effect on mortality of stopping smoking after unstable angina and myocardial infarction. Br Med J 1983;287:324-6.

46. Moher M: Evidence of effectiveness of interventions for secondary prevention and treatment of coronary heart disease in primary care. Oxford: Anglia and Oxford Regional Health Authority, 1995.
47. Pyrola K, De Backer G, Graham I: Prevention of coronary heart disease in clinical practice. Recommendations of the task force of the European Society of Cardiology, European Atherosclerosis Society and European Society of Hypertension. European Heart J 1994;15:1300-31.

48. Wiles R: Patient's perceptions of their heart attack and recovery: The influence of epidemiological "evidence" and personal experience. Soc Sci Med 1998;46(11):1477-86.

49. Mullen K: A question of balance: health behaviour and work context among male Glaswegians. Society Health and Illness 1992;14(1): 73-95.

50. Backett K, Davison C: Rational or reasonable? Perceptions of health at different stages of life. Health Edu J 1992;51(2):55-9.

51. Blaxter M, Cyster R: Compliance and risk taking: the case of alcoholic liver disease. Sociology of Health and Illness 1984;6(3): 290-310.

52. Anderson JJ, Metz JA: Contributions of dietary calcium and physical activity to primary prevention of osteoporosis in females. J Am College Nutr 1993;12(4):378-83. 